\title{
Miranda
}

Revue pluridisciplinaire du monde anglophone /

Multidisciplinary peer-reviewed journal on the English-

speaking world

23 | 2021

Modernist Exceptions

\section{Meet 600 HIGHWAYMEN}

Interview

\section{Emeline Jouve}

\section{OpenEdition}

Journals

Electronic version

URL: https://journals.openedition.org/miranda/42854

DOI: 10.4000/miranda.42854

ISSN: 2108-6559

\section{Publisher}

Université Toulouse - Jean Jaurès

\section{Electronic reference}

Emeline Jouve, "Meet 600 HIGHWAYMEN", Miranda [Online], 23 | 2021, Online since 13 October 2021, connection on 29 November 2021. URL: http://journals.openedition.org/miranda/42854 ; DOI: https:// doi.org/10.4000/miranda.42854

This text was automatically generated on 29 November 2021.

\section{(c) (i) $\odot$

Miranda is licensed under a Creative Commons Attribution-NonCommercial-NoDerivatives 4.0 International License. 


\section{Meet 600 HIGHWAYMEN}

Interview

Emeline Jouve

\section{Website}

600 Highwaymen: https://www.600highwaymen.org/

Interview 
Figure 1

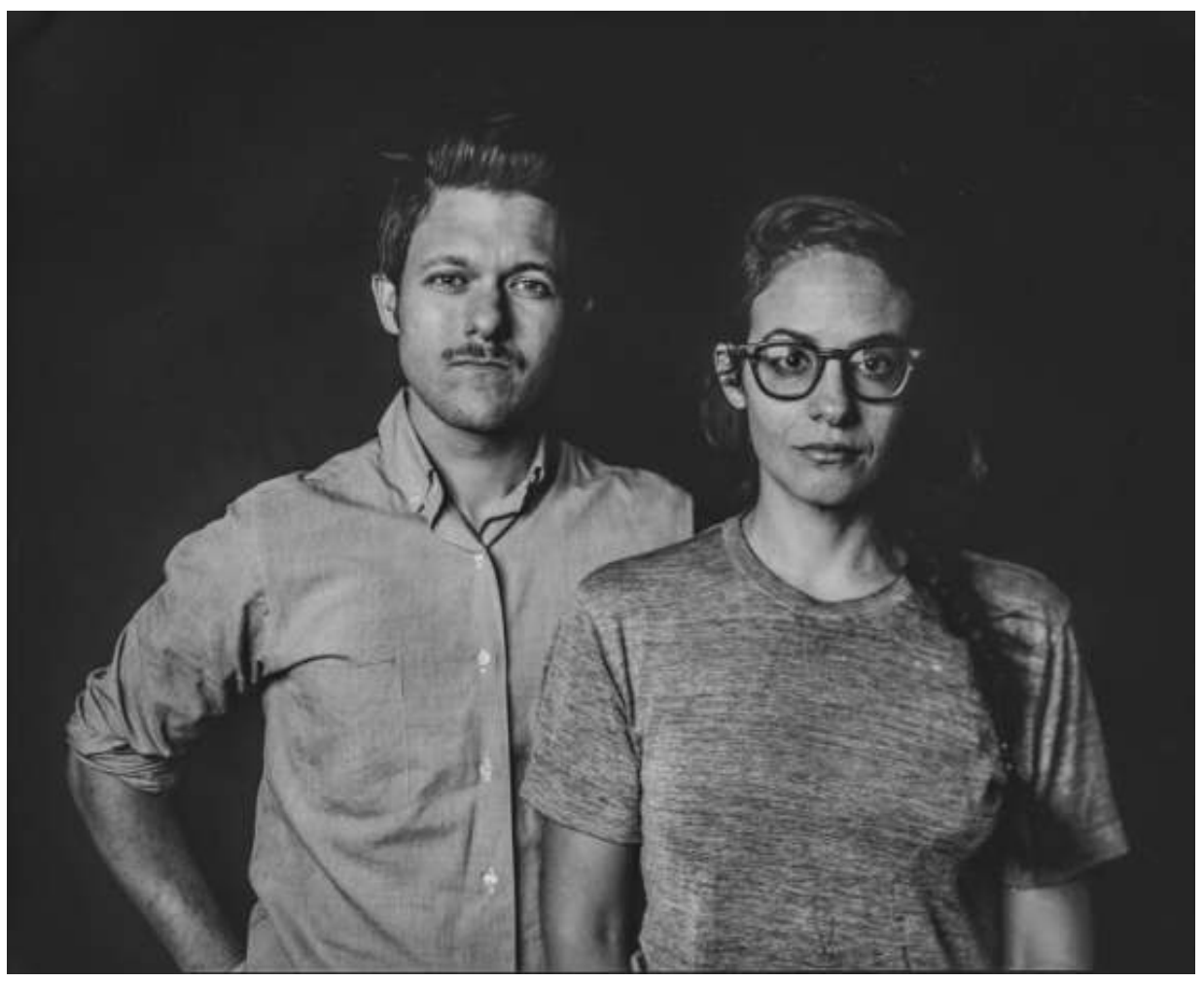

Michael Silverstone and Abigail Browde

Credits : Maria Baranova

Emeline Jouve: First of all, thanks a lot for having accepted my invitation. You and Abigail Browde graduated from Tisch School of the Arts: could you come back on your training and how inspirational it was for your future career?

Michael Silverstone: What was most inspirational was the incredible group of teachers, who became colleagues and mentors throughout our career.

The education was always in the doing, and the dealing with the doing. We were required to work quickly and all the time. Regardless of what we arrived to New York to study, we were all required to write, direct, perform, design, and choreograph our own small projects, and on a relentless basis. In any given day, you are showing 5 or 6 different things you had made and rehearsed in hallways and apartments the night before. There wasn't time for postulating or being academic. We made props and set pieces out of things we found on the street. The expectation was that our work be personal. There was also critique and discussion around the work, which meant early on you are required to develop a thick skin.

E.J.: Did you create the company right after your graduation?

MS: Abby and I didn't set out to create a company. We were making work, and the company came out of it.

E.J.: What was the urge behind the creation of 600 HIGHWAYMEN? Did you feel frustrated with the artistic offer of the time and did you feel the need to innovate?

MS: I don't remember frustration, I remember excitement. I wanted to make performances and I wanted to work with Abby. I was inspired by the spaces where we worked, and the people we cast. 


\section{E.J.: Where does the name "600 HIGHWAYMEN" come from?}

MS: It came from Samuel Beckett's Waiting for Godot.

E.J.: The presentation of your company on your website reads as follow:

Since 2009, 600 HIGHWAYMEN (Abigail Browde \& Michael Silverstone) have been making live art that, through a variety of radical approaches, illuminates the inherent poignancy of people coming together. The work exists at the intersection of theater, dance, contemporary performance, and civic encounter. ${ }^{1}$

Your work is introduced as "radical": could you define this term? Do you see your pieces as avant-gardist?

MS: It's about experimenting in and around the root of some idea, and when you find the heartbeat of it, putting it in the room in it's most raw form. If others find it to be radical or avant-garde, that's for them to say. That's not our job.

E.J.: What about the reference to the "intersection" of different genres? Are you creating a new hybrid genre?

MS: We don't think in terms of genre. The work leads, and as it moves it takes on qualities and forms. Our job is to make something. If people want to categorize something, that's their problem.

E.J.: Could you come back on the notion of "civic encounter"?

MS: There is a civic encounter in performance work that is the search for connection between the performers and the audience.

E.J.: Would you say that your work has a political dimension?

MS: To the extent that we explore the human condition, it may resonate in a political sense to the people who participate-both spectators and performers.

Figure 2

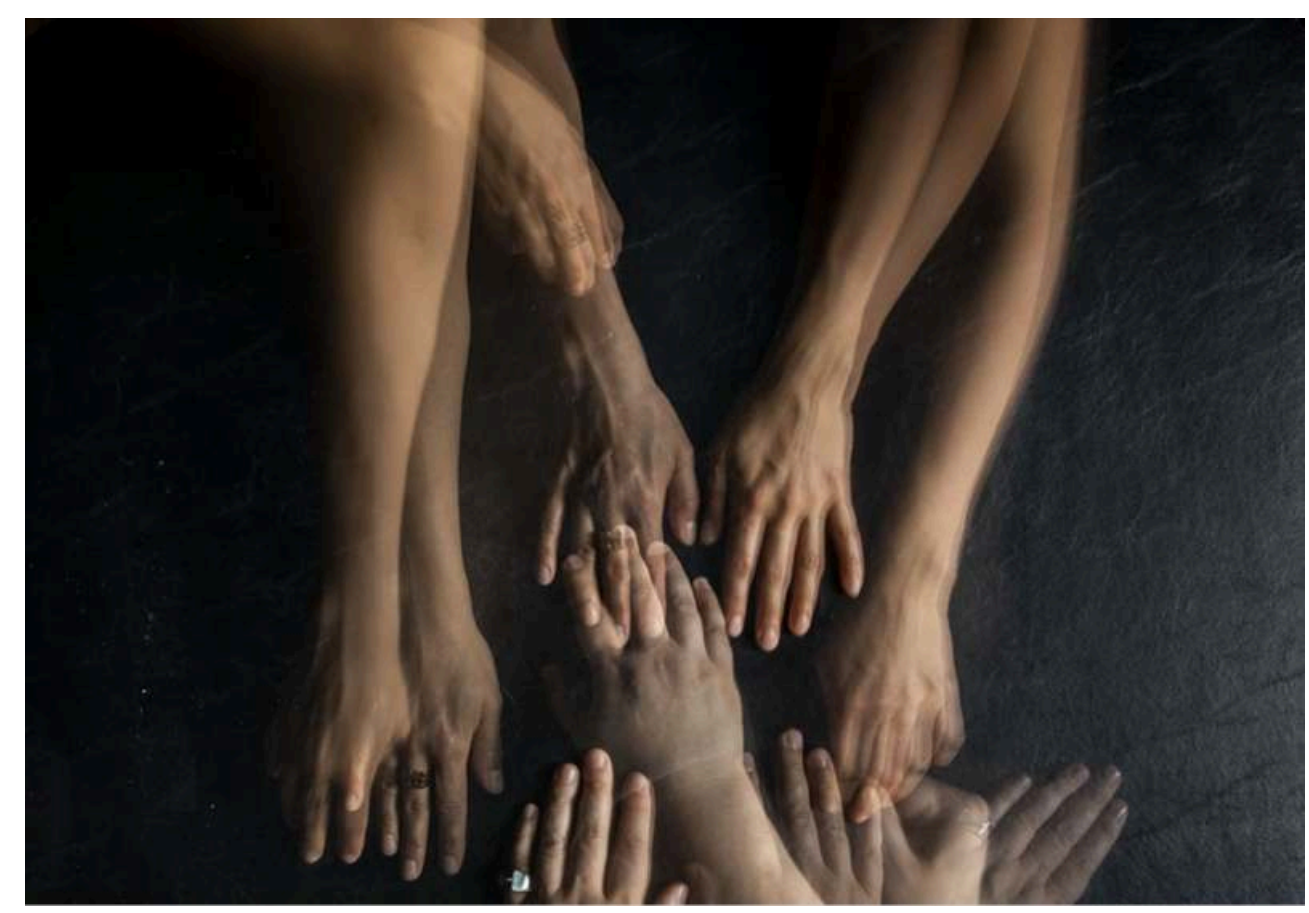

A Thousand Ways

Credits : Maria Baranova 
E.J.: Your current production A Thousand Ways is touring in Europe and in the USA. The first part of this triptych premiered at On The Boards in Seattle in September 2020. Indeed, $A$ Thousand Ways (Part One): A Phone Call is a guided phone conversations with strangers and therefore can take place remotely. Part Two entitled An Encounter opened-before Part Oneat Festival Theaterformen in July 2020 and consists in a meeting between the two strangers. Many theatres around the world were then closed but your shows provided an alternative to the lockdown. Part Three, An Assembly, is a public gathering of all the participants in the previous parts. Was this triptych inspired by the pandemic?

MS: Yes. But we started working on A Thousand Ways before the pandemic. We wanted to create something that brought two people together across a divide.

E.J.: In these times of social distancing, many companies have either offered online versions of past productions or experimented with Zoom but you did not chose this option, why?

MS: Because that doesn't appeal to us, and we didn't want to. We want to continue to create, not just publish what we already created. And the zoom doesn't push us to create in new ways.

E.J.: Although you do not view your work in terms of genres, can we however say that $A$ Thousand Ways is more akin to a performance?

MS: With respect to A Thousand Ways, it is a performance.

E.J.: The dichotomy between absence/presence is central in this piece. Can you come back to this tension?

MS: The dichotomy between absence and presence is in the piece. But it's in there so that they-the two participants-can feel it and deal with it in their own.

E.J.: I would like to focus on Part One. You chose the phone as a mediator to the show. Is the absence of the physical stage or of the screen a way to abolish space?

MS: No. If anything, it's to create space.

E.J.: What kind of encounter between two strangers did you have in mind?

MS: We did not have a preconception of the encounter. We wanted to allow the two people to explore their own connection.

E.J.:How did you work on the questions to guide the conversation?

MS: In the questions we're formulating, we're asking the respondent to reveal pieces if the lives, which allows the listener to arrive at an understanding of who that other person may be.

E.J.: The recorded voice giving the directives is very mechanical. It does not sound human at all. I guess that it was made on purpose, was it?

MS: Yes. The mechanical nature of the robot emphasizes the humanity of the callers.

E.J.: The virtual voice keeps repeating that "words are not enough" and she add that "they are the only things that we have". Yet, during the exchange, the participants are not only asked to use words (and to repeat sentences, to answer questions) but their bodies are also involved (as they are told to move around, to make gestures) and they are invited to create images (by picturing scenes). Was this multiplicity of approaches a way to illustrate the fact that words are actually not the only things left (in a time of lockdown)?

MS: Language and words are the medium of the piece. Our exploration is how do we use language and talking to get at something more dimensional.

E.J.: Do you consider that the participant is a performer in your piece?

MS: Of course. 
E.J.: The conversation is strictly framed and the participants cannot get out of this frame which may be frustrated at times. Did you consider giving more leeway to the participants?

MS: We did. And we decided against it. Because the piece exists in its restrictions. It's not a conversation, and we found that there was a potency to restricting people's responses. The discursive nature of conversation is not as interesting as the more pointed.

E.J.: Part One: A Phone Call is touring in Europe and in the USA: do you get different responses depending on the country the show is programmed?

MS: Not really.

E.J.: Can you tell us more about Part Two and Part Three?

MS: Part Two and Part Three are steps toward opening up and coming back together again.

E.J.: Do you think that the pandemic will have long-term consequences on the world of the performing arts and on your own company? Has a new form of theatre emerged, would you say? Will artists think about art forms and the relationship with the audience differently? What about your own approach?

MS: The pandemic has changed the world. How can we separate art from everything else? It's all changing.

E.J.: Regarding the financing of the arts: How the world of tomorrow will be like, do you think?

MS: We expect it will change. How and when remains to be seen.

E.J.: Michael Silverstone, thanks a lot.

\section{NOTES}

1. “About 600 Highwaymen” http://www.600highwaymen.org/about/

\section{ABSTRACTS}

Interview with Michael Silverstone, cofounder of the company 600 HIGHWAYMEN with Abigail Browde. The interview was conducted by emails from May, $7^{\text {th }}$ to August, $17^{\text {th }}$.

Entretien avec Michael Silverstone, co-fondateur avec Abigail Browde de la compagnie 600 HIGHWAYMEN. L'échange a été conduit par courriel entre le 7 mai et 17 août 2021. 
INDEX

Mots-clés: théâtre, États-Unis, rencontre, pandémie, 600 HIGHWAYMEN A Thousand Ways Keywords: theatre, USA, civic encounter, pandemic, 600 HIGHWAYMEN A Thousand Ways Subjects: Theater

\section{AUTHOR}

\section{EMELINE JOUVE}

Maîtresse de Conférences

Université Toulouse-Jean Jaurès

emeline.jouve@univ-tlse2.fr 